\title{
Tidal rhythmites: geochronometers for the ancient Earth-Moon system
}

Inquiry into the history of both the Earth's rotation and the lunar orbit through the analysis of growth increments in marine invertebrate fossils has stalemated in recent years because of uncertainties in the interpretation of various fossil structures. Cyclically laminated and thin-bedded rhythmites of tidal origin, recently recognized in Precambrian and Paleozoic deposits, provide the timely prospect that sedimentary rocks independently may record paleotidal and paleorotational data that support and extend the paleontological findings.

Late Proterozoic clastic ebb-tidal rhythmites in South Australia indicate about 400 days and 13.1 lunar months per year and about 21.9 hours per day at about 650 million years $(\mathrm{Ma})$, as well as other paleotidal periods. Tidal rhythmites of likely estuarine origin that occur widely in the Carboniferous of the east-central United States are a potential source of such information for the late Paleozoic. Early Proterozoic banded iron-formation in Western Australia may provide paleotidal data for about 2,500 Ma. The Proterozoic data apparently rule out a close approach of the Moon during the past 3,000 Ma. Overall, the study of tidal rhythmites promises to illuminate greatly the history of the Earth's rotation and the Moon's revolution.

\section{Introduction}

A seviewed by Lambeck (1980), the problem of integrating the present lunar orbit with the history of the Earth's rotation and the Moon's revolution under the influence of tidal friction was first addressed by George Darwin in the 19th century. The consequences of the backward extrapolation of the present rate of lunar recession are well known: the Moon would have been within the Roche limit of the Earth. where tidal forces would disrupt the Moon, at about 1.500 Ma. However. neither the geologic records nor surface features of the Earth or the Moon provide evidence of such a catastrophe at that time, and stromatolite growth patterns indicate the presence of lunar tides at 3.000 Ma (Pannella. 1976). Clearly, an understanding of the dynamic evolution of the Earth-Moon system through geologic time is of major importance, not only to Earth history but also to studies of the Moon's origin.
Wells (1963) provided the first direct estimate of the number of days per year in the geologic past from his study of postulated annual and daily growth increments in Paleozoic corals. Wells's work raised the hope that at least the later history of the Earth's rotation and the Moon's orbit could be traced accurately from the study of skeletal growth increments in fossils (see Runcorn, 1966). For more than two decades, such paleontological studies provided the only means with the potential to determine directly the history of the Earth's despin and the Moon's revolution. In general, studies of growth cycles in coral and mollusk fossils have indicated a greater number of days per year, days per lunar month, and lunar months per year going back through the Phanerozoic (see Rosenberg and Runcorn, 1975; Brosche and Sündermann, 1978). These findings are in accord with the hypothesis of lunar tidal friction, which holds that angular momentum is transferred from the Earth's rotation to the Moon's orbital motion by the action of the lunar tidal torque mainly on the oceans.

The great expectations held for such paleontologic geochronometers have not, however, been entirely fulfilled. After comprehensive review of the topic, Scrutton $(1978$, p. 182) decided that none of the published data are wholly satisfactory. The common assumption that the data reflect the solar day and lunar (synodic) month may not be justified; even data from bivalves, the most promising source, "are likely to be inaccurate because of earlier misunderstanding of the interplay between lunar and solar day stimuli and the effects of tide type." Scrutton concluded that all the available figures to that time "should be treated as approximations rather than as precise quantities for mathematical analysis." Furthermore, the reliability of paleorotational data for Precambrian time based on stromatolite growth patterns is unclear (see Hofmann. 1973; Pannella, 1975, 1976: Vanyo and Awramik, 1985). Consequently, work on paleontologic "clocks" seems to have reached an impasse, and little progress has been made in this field over the past decade.

The study of newly recognized, rhythmically laminated. and thin-bedded sediments ("rhythmites") of tidal origin promises to rejuvenate geochronometric analysis of the Earth-Moon system. The periodicities recorded by such rhythmites usually can be ascribed to tidal patterns and type and thus avoid some of the uncertainty associated with paleontologic data. In addition, rhythmite sequences may span many years - the longest continuous sequence so far recognized is about 60 years (Williams, 1988, 1989a. b) -and this enhances the reliability of the identified cycles. Such a long rhythmite record also permits the determination of long-term paleotidal periods that cannot be obtained from paleontologic data. Tidal rhythmites are of much greater potential value in the determination of paleotidal periods than are the earlier recognized cross-bedded "bundle" deposits of subtidal origin (see Visser, 1980; Allen. 1982); cross-bedded bundle sequences commonly are abbreviated and usually span intervals much shorter than a year.

This paper discusses the sedimentology and depositional environments of probable tidal rhythmites from the Late Proterozoic of South Australia, the late Paleozoic of North America, and the Early Proterozoic of Western Australia. as well as the implications of the paleotidal and paleorotational data for the history of the Earth-Moon 
system. The study of such tidal rhythmites eventually may allow the evolving dynamics of the Earth-Moon system to be traced over much of geologic time.

\section{Late Proterozoic tidal rhythmites in South Australia}

Late Proterozoic cyclic rhythmites of proposed tidal origin in South Australia (Williams, 1988, 1989 a. b) occur in the Elatina Formation and its correlative the Reynella Siltstone, both deposited at $650 \mathrm{Ma}$ in the Adelaide geosyncline (Preiss. 1987) during the Marinoan glaciation, as well as in siltstones immediately overlying the Chambers Bluff Tillite, which dates from 650 to $800 \mathrm{Ma}$. The rhythmites comprise laminae that range from about $0.2 \mathrm{~mm}$ to $2 \mathrm{~cm}$ in thickness and commonly are graded from fine-grained sandstone at the base to clayey siltstone or a mudstone layer at the top (figs. la-c). Some laminae consist of two graded layers that I have termed "semilaminae." a feature best seen in the Reynella Siltstone (fig. Ib).

A feature characteristic of the rhythmites is the arrangement of laminae in conspicuous groups called "lamina-cycles." The number of discrete laminae per lamina-cycle ranges from 8 to 16 in the Elatina Formation, up to 14 or 15 in the Reynella Siltstone, and up to 25 in the Chambers Bluff Tillite. Lamina-cycles commonly are bounded by clayey bands where thinner laminae merge together: scouring and evident erosion of the cycles occur at such bands in the Chambers Bluff Tillite (fig. 1c). The laminae bounding thick cycles in the Reynella Siltstone (fig. 1b) can be seen in photographic enlargements and suggest that lamina counts for such cycles are reliable. With regard to longer periodicities, a pair of cycles consisting of a thick and a thin lamina-cycle referred to as a "doublet" (figs. $\mathrm{la}, \mathrm{c})$ is common in all three rhythmite sequences. In addition, a long time series of 1,580 lamina-cycle thickness measurements obtained from drill core of the Elatina rhythmites indicates that a mixture of long-term cycles is recorded by variations in lamina-cycle thickness.

Any new physical model proposed for rhythmite deposition must explain the following observations:

(1) Laminae in the Elatina Formation. including the very thinnest laminae, can be correlated in drill cores from holes $200 \mathrm{~m}$ apart along a north-south line. The commonly graded laminae probably were deposited mainly from suspension in quiet waters below wave base.

(2) Paleoslope directions for the Elatina rhythmites, as indicated by slumps in drill cores, are to the east. that is, directly away from the inferred shoreline along the nearby western margin of the Adelaide geosyncline. Isolated climbing ripples indicate movement of sediment down this paleoslope by eastward-flowing currents.

(3) A tidal influence is suggested by clayey drapes within isolated climbing ripples that pass laterally into the Elatina laminar rhythmites (fig. 1d). This is suggested also by herringbone crossbedding in sandstones overlying the rhythmites of the Reynella Silttone (fig. le).

These observations and the complex cyclicity displayed by all the rhythmites can be explained by deposition of material from turbid ebb-tidal currents in an offshore marine setting (Williams. 1987. 1988. 1989a b). In this tidal model. fine-grained sediment is entrained by ebb-tidal currents in tidal inlets and is transported. mainly in suspension, by turbulent ebb-tidal jets to deeper water offshore (see Ozsoy, 1986). Once offshore, the suspended sediment would settle and form graded laminae and local small-scale ripples (see Rees. 1966) in a distal ebb-tidal delta or a marine shelf environment fig. 2) below effective wave base.
The effectiveness of the tide as an agent of such entrainment and deposition would be determined by the speed of the ebb tide and the tidal range (FitzGerald and Nummedal, 1983; Boothroyd, 1985), as the potential sediment load of ebb-tidal currents may increase linearly with tidal range (fig. 3 ) and current speed. Hence, relatively thick laminae on the distal delta or shelf normally would be associated with fast ebb-tidal currents and large tidal ranges, such as occur during the spring phase of the tidal cycle. Thin clayey caps could form on sandy laminae during slack water between tides. As movement of sediment by tides may cease below a threshold tidal range and current speed (Allen, 1982; FitzGerald and Nummedal. 1983; see also fig. 3), pauses in deposition of sandy laminae in the distal setting might occur for small, neap-tidal ranges; the quieter waters at such times would allow the settling of additional fine-grained material and the deposition of distinct clayey bands between fortnightly groups of laminae (fig. 2, bottom inset). Factors that would enhance the preservation of distal laminae include low wave energy and relatively rapid deepening beyond the terminal lobe of the ebb-tidal delta. Similarly, deposition of cross-bedded, cyclic "bundle" sequences of shallow-water, subtidal deposits (fig. 2, top inset) is explained by unidirectional or strongly asymmetrical tidal currents effecting deposition: a direct relation between clastic cross-bed thickness. tidal range, and current speed; and the association of mud layers and drapes with slack water and neap tides (Visser, 1980; Allen 1981. 1982).

As discussed by Williams (1988, 1989a, b), this tidal model allows interpretation of lamina-cycles in the Late Proterozoic rhythmites as groups of tidal laminae that record the spring or fortnightly tidal cycle, and clayey bands that mark neap tides between cycles. By this interpretation, the laminae of the Elatina Formation and the Reynella Siltstone are regarded as diurnal increments representing the lunar day, and the semi-laminae of the Reynella Siltstone and the laminae of the Chambers Bluff Tillite are regarded as semidiurnal increments of the lunar day. Thus, the apparent tidal patterns displayed by these formations would be dominantly diurnal, mixed, and semidiurnal, respectively (fig. 4). Apparently the Elatina sedimentary system usually filtered out the lesser semidiurnal component of the diurnal inequality. The dark bands of clayey material bounding many lamina-cycles would mark horizons of arrested clastic deposition and the abbreviation of cycles at neaps. Figure 4 shows in a general way the tidal ranges that effected deposition of clastic laminae in the rhythmites. The Reynella Siltstone, which contains some relatively thick, unabbreviated lamina-cycles, suggests a more proximal setting than that of the other rhythmites.

As progradation of the tidal environments shown in figure 2 takes place. the expected upward succession of facies (as adapted from regressive tidal facies illustrated by Rahmani, 1988: Hayes, 1989) would be: offshore shelf muds. prodelta abbreviated distal and unabbreviated proximal rhythmites. mainly flat-bedded and crossbedded sand facies of the swash platform and ebb-tidal delta, sand facies of tidal channels containing cross-bedded tidal "bundle" deposits, beach and dune sands, and tidal-flat and salt-marsh deposits. The hypothesis that the Late Proterozoic rhythmites. in particular those of the Elatina Formation, are of distal ebb-tidal origin must be tested by searching for comparable rhythmites in ebb-tidal sequences elsewhere. both modern and ancient.

It is intriguing that the Late Proterozoic rhythmites in South Australia apparently are restricted to or associated with glacial formations. Glacial and periglacial conditions would, of course. produce an abundance of fine-grained clastic material that could be transported in suspension. and the high viscosity of very cold waters (see Allen. 1982) would assist such transport. In addition, tidal ranges and the speed of tidal currents may have been amplified by tidal resonances within the gulf-like Adelaide geosyncline. 

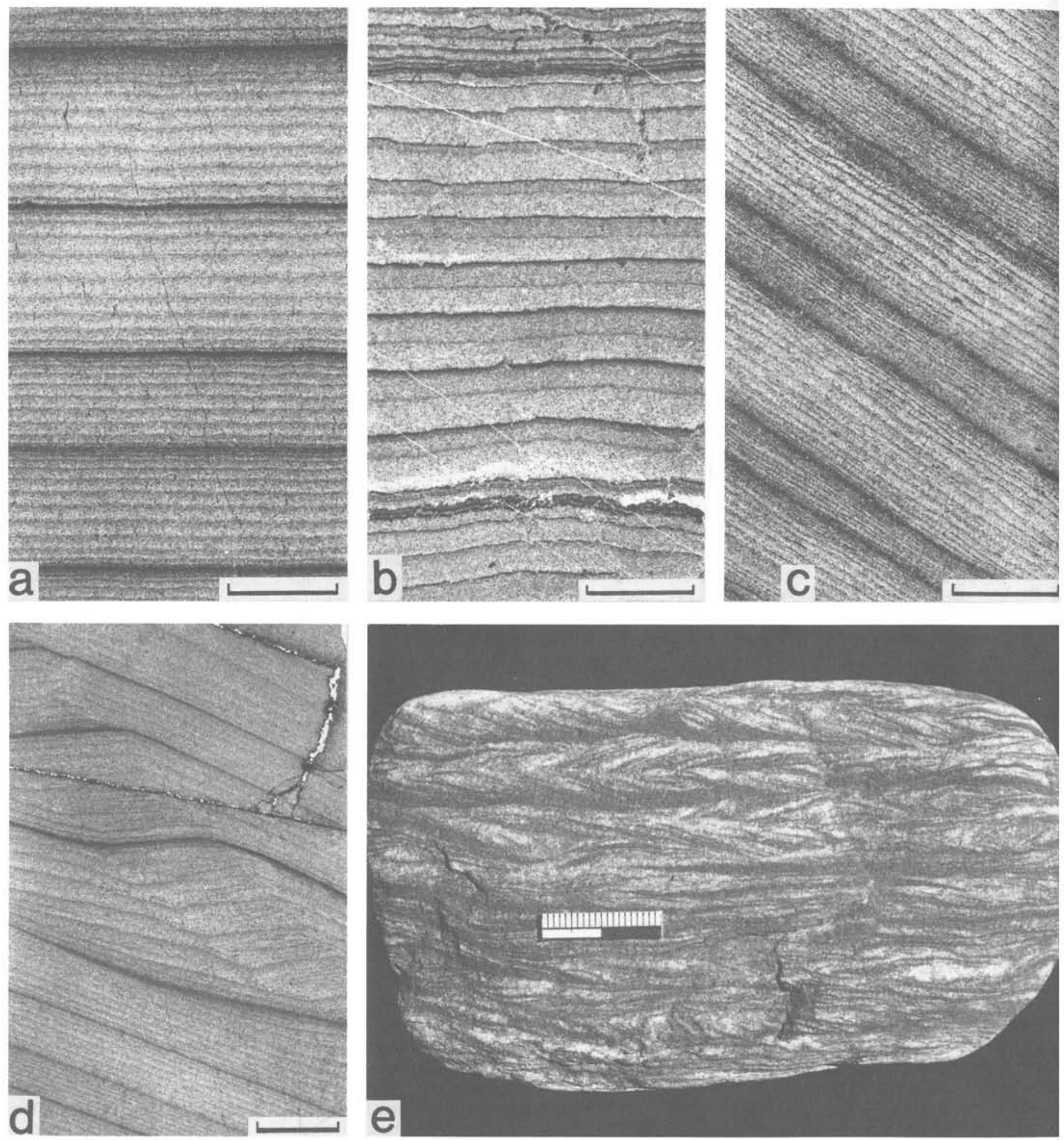

Figure 1.-Late Proterozoic tidal deposits, South Australia. Clayey material appears darker than sandy to silty layers. Scale bars are $1 \mathrm{~cm}$ long for figures a-d. a, Elatina Formation. Four complete lamina-cycles each of about 10 to 14 graded laminae are bounded by thin clayey bands. $b$, Reynella Siltstone showing 1 complete, thick lamina-cycle that contains 14 laminae of fine-grained sandstone, each having a clayey top. Most laminae show "semi-laminae." $c$, Chambers Bluff Tillite showing 7 complete, alternately thick and thin lamina-cycles that each total from 15 to 25 graded laminae. Laminae are eroded in places at tops of cycles. $d$, Rhythmite cycles of the Elatina Formation that pass laterally into isolated climbing ripples and have dark clayey drapes between sets of cross-laminated fine-grained sandstone; current from the right. e, Herringbone cross-bedding in sandstone facies of the Reynella Siltstone; scale bar is $2 \mathrm{~cm}$ long. Specimens $c$ and d are from drill core and show tectonic dip. 


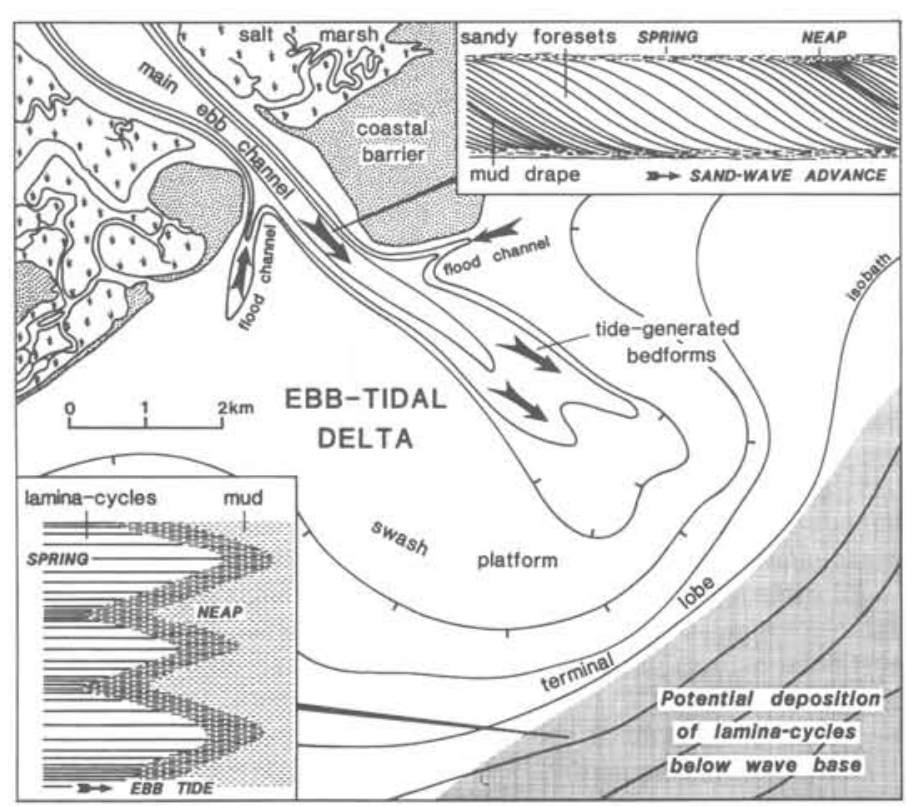

Figure 2.-Postulated environment of deposition for lamina-cycles of the Elatina Formation that uses a hypothetical ebb-tidal delta modified from Imperato and others (1988). Tidal "bundle" sequences of cross-bedded sand (top inset) related to bars and sand waves occur in proximal tidal channels, whereas fortnightly lamina-cycles of finegrained sand and silt (shown schematically in bottom inset) are deposited from suspension in a distal, offshore setting below wave base. With increasing distance from the shore, lamina-cycles become progressively more abbreviated at neaps and eventually pass into shelf muds.

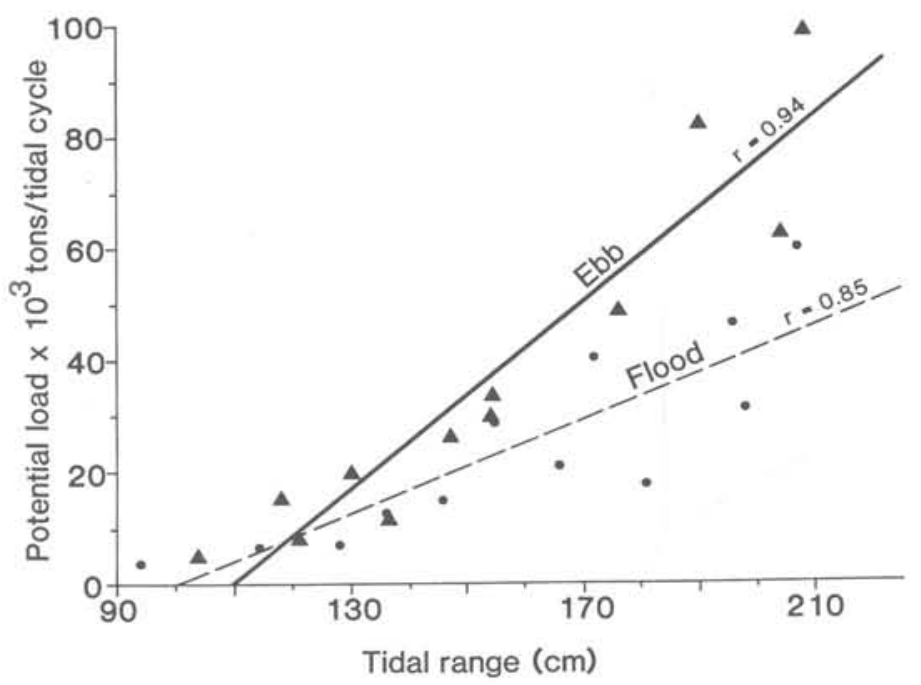

Figure 3.-Potential sediment transport versus tidal range, Price Inlet, South Carolina. From FitzGerald and Nummedal (1983, fig. 7). Triangles are values for ebb tide, and dots are values for flood tide. $r$ is the correlation coefficient for the regression lines shown.

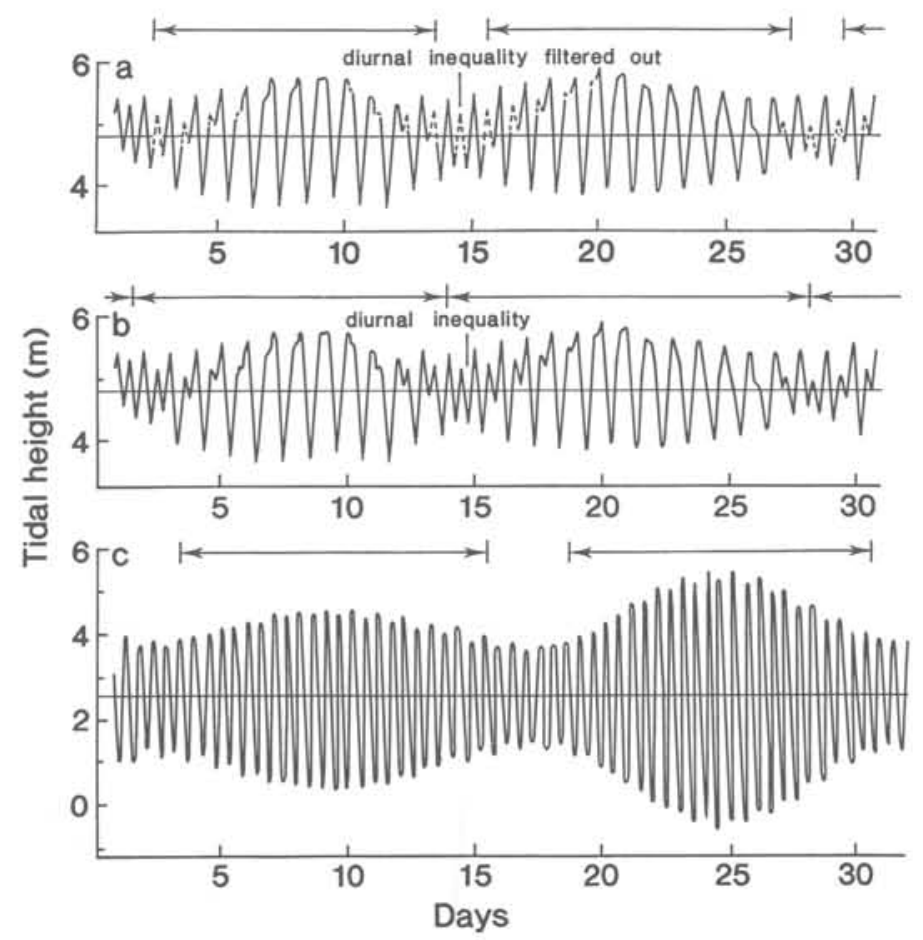

Figure 4.-Modern tidal patterns (from Godin, 1972, and Lisitzin, 1974). a, Apparently diurnal (as usually displayed by the Elatina Formation, see fig. Ia), derived from a mixed tidal pattern with the lesser semidiurnal component (dashed) of the diurnal inequality filtered out. b. Mixed (as displayed by the Reynella Siltstone, see fig. $1 b$ ). $c$, Semidiurnal (as displayed by the Chambers Bluff Tillite, see fig. $1 c$ ). The arrows show schematically the tidal ranges that effected the deposition of clastic laminae for respective Late Proterozoic rhythmites.

\section{Late Proterozoic paleotidal and paleorotational periods}

The remarkable similarity between cyclic patterns displayed by the Elatina Formation and those of modern synodic tides are evident in figures 5-7 (maximum tidal heights are plotted in figs. 5 and 6 , as they are a relative measure of tidal range). Indeed, the Elatina rhythmites provide such a detailed record of paleotidal variations over a 60-year interval that a full spectrum of paleotidal and paleorotational periods can be determined for $650 \mathrm{Ma}$ (table 1). Such findings hitherto were not possible for any geologic period.

Table 1.-Late proterozoic $(650 \mathrm{Ma})$ and modern tidal and rotational periods

\begin{tabular}{|c|c|c|}
\hline Parameter & Late Proterozoic* & Modern \\
\hline Solar days in lunar month. & $30.5 \pm 0.5$ & 29.53 \\
\hline Lunar months in year ..... & $13.1 \pm 0.1$ & 12.37 \\
\hline Lunar perigee cycle (years) & $9.7 \pm 0.1$ & 8.85 \\
\hline Lunar nodal cycle (years). & $19.5 \pm 0.5$ & 18.61 \\
\hline Solar days in year. & $.400 \pm 7$ & 365 \\
\hline Length of solar days (hours) & $21.9 \pm 0.4$ & 24.0 \\
\hline
\end{tabular}

* Periods indicated by the rhythmites of the Elatina Formation and Reynella Silstone (Williams, 1987, 1988, 1989a, b). Revised error estimates for all parameters except days per month and nodal cycle are standard deviations based on fast Fourier transform spectra (see Williams, 1989c). 

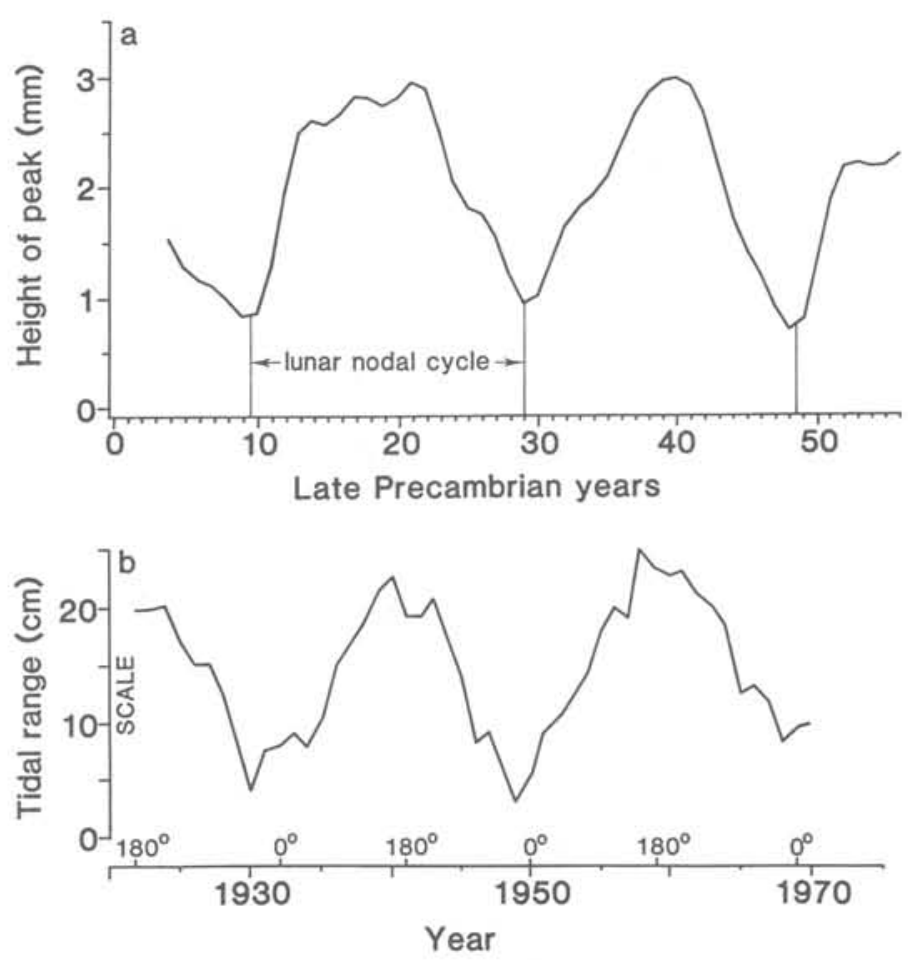

Figure 7.-a, Curve showing the variation in the height of the halfyearly tidal signal (second-order peak of the yearly cycle) in the Elatina Formation rhythmites. The height was measured from the base of the deep trough to the top of the secord-order peak throughout the smoothed curve of lamina-cycle thickness (see fig. 6 b) and was then further smoothed. The height is modulated by a period near 19.5 years, as marked by the vertical lines. $b$, Annual mean tidal range for Boston, Massachusetts, which is dominated by the 18.6-year lunar nodal cycle. Years when the Moon's nodes were $0^{\circ}$ and $180^{\circ}$ in longitude are indicated. From Kaye and Stuckey (1973).

\section{Other possible tidal rhythmites}

Because paleotidal deposits are distributed widely in the stratigraphic record (see de Boer and others, 1988), it is surprising that tidal rhythmites like those of Late Proterozoic age in South Australia have not been recognized more often. The apparent rarity of such deposits in the Phanerozoic record may, in part, reflect their vulnerability to bioturbation, yet I suspect that tidal rhythmites may be fairly widespread and have been overlooked or not recognized by geologists.

Rhythmically laminated to thin-bedded siltstones interpreted as tidalites are indeed widely distributed in the Carboniferous coal measures of Illinois and Indiana (Broadhurst, 1988; Kvale and others, 1989). These rhythmites comprise graded laminae and thin beds of silt that vary from millimeters to several centimeters in thickness and commonly are arranged in pairs and capped by thin mudstone bands (fig. 8). The siltstone units have been interpreted as diurnal and semidiurnal increments, and the mudstone bands have been attributed to deposition during slack water between tides. The rhythmites are up to $10 \mathrm{~m}$ or more thick and may record tidal oscillations over intervals of up to 10 years. This rhythmite facies, which may be preserved in estuarine settings, gives promise of providing paleotidal and paleorotational periods for Carboniferous time. Such data would allow comparison with findings from contemporaneous fossil growth patterns.
A most exciting prospect is that tidal rhythmites will be found that record information on the dynamics of the Earth-Moon system very early in its history. Cyclic rhythmites in banded iron-formation (BIF) of the Weeli Wolli Formation, Hamersley basin, Western Australia, may well provide paleotidal periods for about $2,500 \mathrm{Ma}$, although earth-tidal rhythms may be recorded rather than ocean-tidal rhythms. The cyclicity in the Weeli Wolli Formation (figs. 9a, b) arises from regular variations in thickness of both the chert and hematite parts of microband couplets, giving the facies a characteristic striped appearance. The microbands usually are very thin $(0.05 \mathrm{~mm}$ thick or less), and only the cyclic stripes are readily discernible (fig. 9b). Local pods of chert have better resisted diagenetic compaction, however, which allows the microbands to be more easily seen and counted (fig. 9a). Counts I have carried out on thin sections of chert

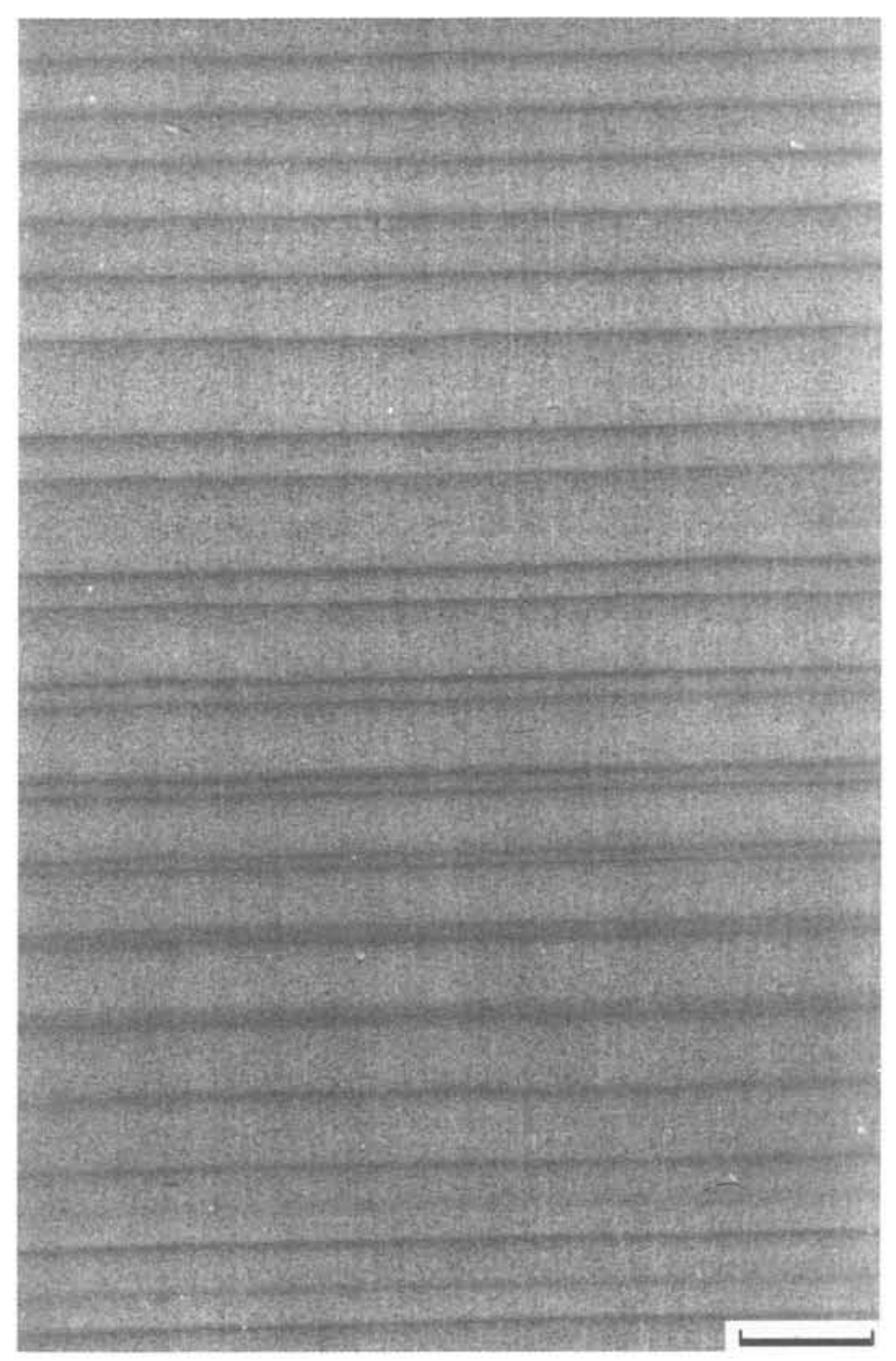

Figure 8.-Rhythmite of siltstone and mudstone laminae of postulated tidal origin from the upper Carboniferous Francis Creek Shale, Illinois. Scale bar is $1 \mathrm{~cm}$. The paler, silty laminae may be interpreted as diurnal and semidiurnal increments, and the darker, mudstone bands as deposits during times of tidal slack water. Variation in lamina thickness reflects the changing speed of tidal currents during the neap-spring cycle. From Broadhurst (1988, fig. 19.6). Reproduced by permission of Blackie and Son Ltd., Glasgow, and Dr. F.M. Broadhurst. 

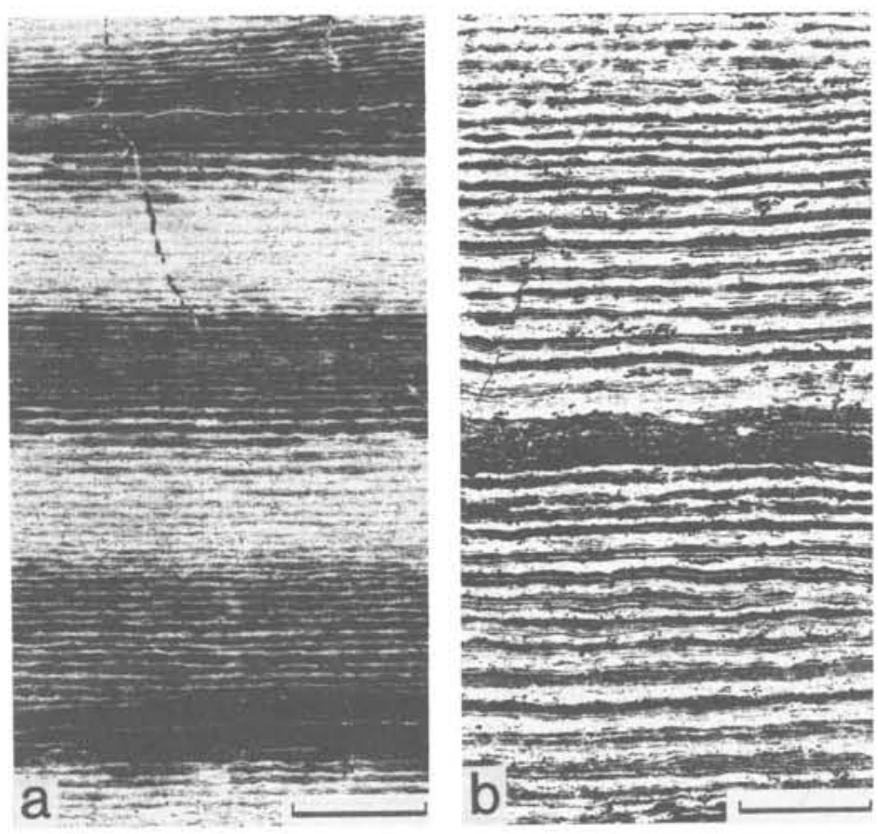

Figure 9.-a, Chert pod from Early Proterozoic cyclic banded iron-formation of the Weeli Wolli Formation, Western Australia. The pod contains discernible microband couplets of chert (white) and hematite (black), and up to about 28 to 30 microband couplets occur between the centers of the cyclic stripes. $b$, Strongly compacted iron-formation from the Weeli Wolli Formation in which only the cyclic stripes are readily discernible. Scale bars are 5 $\mathrm{mm}$.

pods indicate as many as 28 to 30 microband couplets per cycle. Cycles containing fewer microband couplets usually show evidence that some adjacent hematite microbands have amalgamated; counts for such cycles probably underestimate the true cycle period. These observations might suggest a cycle period near 28 to 30 microband couplets, casting doubt on the interpretation of Trendall (1973) that the cycle period is about 23 microband couplets, or years, and reflects the double sunspot cycle.

Submarine, volcanic-associated hydrothermal or fumarolic activity has been proposed for the origin of numerous BIFs (see Simonson, 1985; Fralick, 1987). Such an origin for the Weeli Wolli BIF is supported by the local presence of beds of volcanic ash (Trendall and Blockley, 1970) and by aspects of the BIF geochemistry. Because some geyser activity today is modulated by earth tides (Rinehart, $1972 \mathrm{a}, \mathrm{b})$, the question is raised as to whether the Weeli Wolli cyclicity records earth-tidal rhythms that modulated the discharge of silica- and (or) iron-bearing fumarolic waters. As the primary components of the solid earth tide are semidiurnal and fortnightly, at least two possible tidal interpretations of the Weeli Wolli cyclicity are suggested:

(1) The microband couplets are semidiurnal increments grouped in lunar fortnightly cycles. By this interpretation, there were about 28 to 30 lunar days per lunar month at about $2,500 \mathrm{Ma}$.

(2) The microband couplets are lunar fortnightly increments that are arranged in annual cycles (compare fig. 6) through seasonal influences on sedimentation. This would indicate about 28 to 30 lunar fortnights, or about 14 to 15 lunar months, per year at about 2,500 $\mathrm{Ma}$.

The latter interpretation may be preferred because geothermal areas usually are so sluggish mechanically that the semidiurnal and diurnal components are filtered out, whereas the activity of geysers may be influenced by the fortnightly tidal component (Rinehart, 1974). Furthermore, an annual origin for the Weeli Wolli cyclic stripes gives sedimentation rates for the compacted facies (fig. 9b) that are comparable to presumed rates for other BIFs in the Hamersley Group whose microbanding ("aftbanding") is regarded as annual (see Trendall and Blockley, 1970; Trendall, 1983). Such an origin for the cyclicity also finds support in the presence of between 15 and 27 laminae (depending on the observer) in a thick microband, presumed to be one year's accretion, from the Brockman Iron-formation in the Hamersley basin (Ewers and Morris, 1981).

The Weeli Wolli cyclicity, whatever its origin, is evidently of great potential interest to paleogeophysics. Other BIFs of Archean and Early Proterozoic age should be searched carefully for similar rhythmites.

\section{Implications for the dynamic history of the Earth-Moon system}

$\mathrm{P}_{\text {aleotidal and paleorotational data for Late Proterozoic time at }}$ about $650 \mathrm{Ma}$, as determined from the rhythmites of the Elatina Formation and Reynella Siltstone (table 1), suggest an average equivalent phase lag angle (the angle between the Earth-Moon axis and the Earth's tidal bulge, derived from the response of the solid earth and ocean tides; Lambeck, 1978, 1980) near $3^{\circ}$ since Late Proterozoic time, rather than the present value of $6^{\circ}$ (see Williams, 1989a, b). That is, the mean rate of lunar recession for the past $650 \mathrm{Ma}$ as indicated by the rhythmite data is much less than the present rate of recession. The rhythmite data imply, from change in the number of days per month (see Runcorn, 1979) and in the period of the lunar nodal cycle (Williams, 1989a), as well as from considerations of angular momentum conservation, an Earth-Moon distance of about $58 \pm 1$ Earth radii (some 96 percent of the present distance) at 650 $\mathrm{Ma}$. The low rate of lunar recession for an average lag angle of $3^{\circ}$ argues against a close approach of the Moon any time during the past 3,000 Ma (Lambeck, 1988). These estimates of lunar distance based on an average equivalent lag angle value do not imply, however, that changes in the Earth-Moon system necessarily have been linear. The changing paleogeography of the mobile Earth caused the magnitude of the tidal torque between the Moon and the oceans to vary significantly during the Phanerozoic (Brosche, 1984), and the paleogeography also suggests a reduced tidal torque during the Proterozoic (Piper, 1982).

Late Proterozoic values for the durations of the lunar month anc year (table 1) are compared in figures 10 and 11 with values determined from Phanerozoic fossil data and Proterozoic stromatolites. The value of $13.1 \pm 0.1$ lunar months per year at $650 \mathrm{Ma}$, a figure well defined by the Elatina data, accords with the small decrease in the number of presumed lunar months per year during the course of the Phanerozoic (fig. 10). Interestingly, the value of about 14 to 15 lunar months per year at about $2,500 \mathrm{Ma}$, suggested as one possible interpretation of the cyclicity in the Weeli Wolli Formation, would agree with the overall low rate of lunar recession indicated by the Elatina rhythmite data (fig. 10 , inset).

The value of $400 \pm 7$ solar days per year at $650 \mathrm{Ma}$ seems to be at odds, however, with some paleontologic data for the early Paleozoic (fig. 11). Certainly the number of days per Late Proterozoic year given by the Elatina Formation is not well defined, but the number of solar days per lunar month, upon which days per year partly depends, likely falls within the error estimates shown (table 1). The early Paleozoic values for solar days per year, on the other hand, must be viewed with caution. As shown in figure 11, the available ranges of values are large, two other values are only 

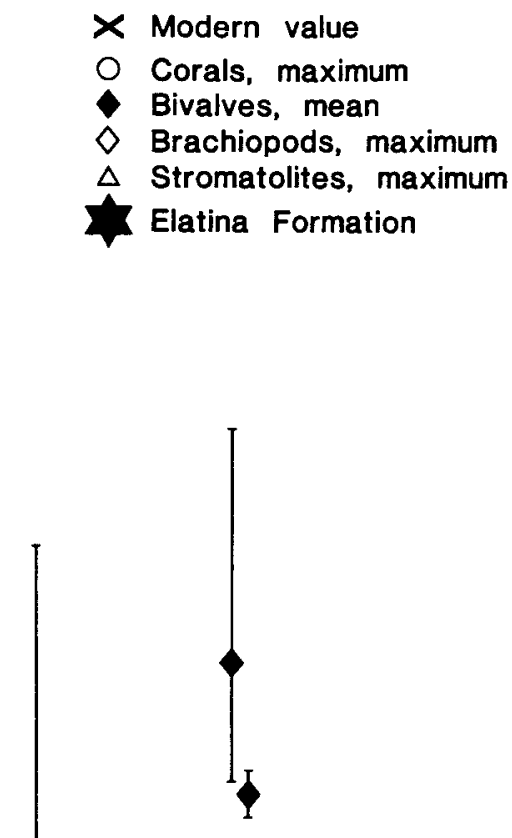

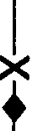
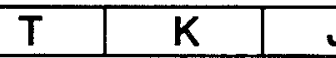

\begin{tabular}{l|l|l|}
$\mathrm{J}$ & $T_{R}$ & $\mathrm{P}$ \\
\hline 2 &
\end{tabular}

100

200

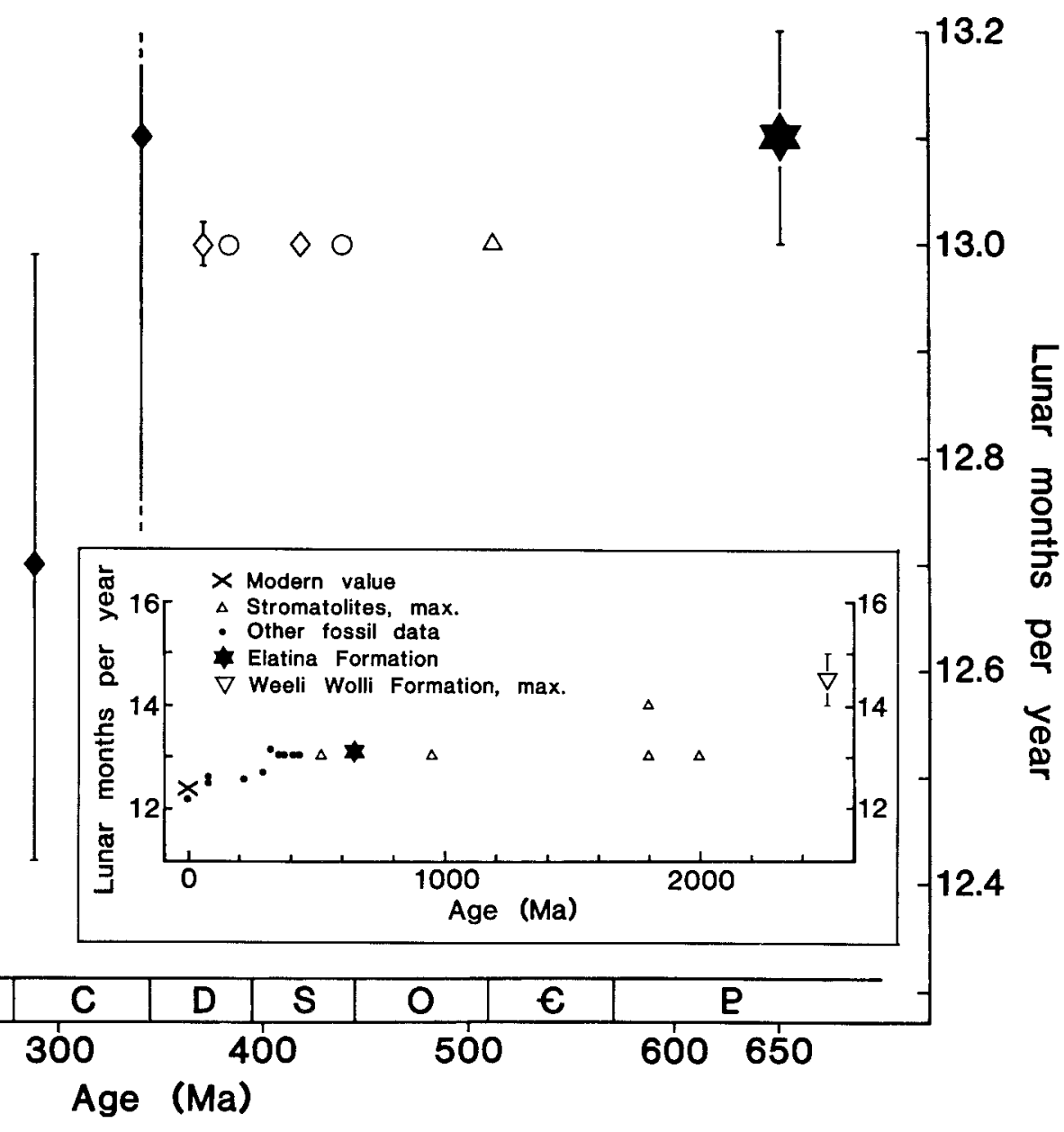

Figure 10.-Plot of presumed lunar months per year as compiled from Phanerozoic paleontologic data (see Scrutton, 1978), with added ranges of values from Berry and Barker (1968), Ma-zullo (197I), and Pannella (1972a) together with the value (plus error estimate, see table 1) indicated by the Late Proterosoic Elatina Formation. The inset shows data for the Proterozoic and Phanerozoic, including the presumed value indicated by the Early Proterosoic Weeli Wolli Formation. Ages taken for Proterozoic stromatolites are Belt Supergroup, 950 Ma (Pannella, 1972a): Gunflint and Biwabik formations, 1,800 Ma (Schopf, 1983); and Great Slave Supergroup, 2,000 Ma (Campbell, 1981). The Weeli Wolli Formation is dated at approximately 2.500 Ma (Trendall, 1983). Abbreviations: max. maximum; P, Precambrian; $€$, Cambrian; $O$. Ordovician; S, Silurian; D. Devonian: C, Carboniferous; P. Permian, K, Triassic: J, Jurassic; K, Cretaceous; and T, Tertiary.

independent values for the number of days and months per year during the Paleozoic through the analysis of tidal rhythmites.

\section{Conclusions}

Analysis of the past dynamics of the Earth-Moon system may be rejuvenated by the study of cyclically laminated and thin-bedded rhythmites of tidal origin, which can record information about the Earth's rotation and the Moon's revolution. Late Proterozoic ebbtidal rhythmites in South Australia evidently provide the first firm benchmark for Precambrian paleotidal and paleorotational values: at about $650 \mathrm{Ma}$, the day was about 21.9 hours long and the year contained about 400 days and 13.1 lunar months. Tidal rhythmites of possible estuarine origin in Illinois and Indiana promise to provide such valuable data for late Paleozoic time. Also, cyclic banded ironformation of possible fumarolic origin in Western Australia may 
record paleotidal information for Early Proterozoic time. The Proterozoic rhythmite data imply an overall low rate of lunar recession that argues against a close approach of the Moon to the Earth at least during the past 3,000 Ma.

Geologists should seek comparable tidal rhythmites throughout the stratigraphic record to provide paleotidal and paleorotational data for other stratigraphic intervals. Special importance should be placed on the search for cyclic rhythmites in Archean banded iron-

formations that might record information for very early earth history. Such sedimentological studies promise to reveal the evolving dynamics of the Earth-Moon system over most of geologic time and may throw light on the origin of the Moon itself.
Figure 11.-Plot of presumed solar days per year based on Phanerozoic paleontologic data compiled by Scrutton (1978), with available ranges of values and additional data from McGugan (1968). Berry and Barker (1968), Wells (1970), Maz-ullo (1971), Pannella (1972a, b), and Vanyo and Awramik (1985) together with the value (plus error estimate, see table 1) indicated by the Late Proterozoic Elatina Formation. The inset includes data for both the Proterozoic and Phanerozoic. Abbreviations: approx., approximate; max., maximum; P, Precambrian; $€$, Cambrian; $O$, Ordovician; S, Silurian; $D, D e-$ vonian; $C$, Carboniferous: $P$, Permian; $\mathbf{k}$, Triassic: J, Jurassic; $K$, Cretaceous; and $T$, Tertiary.

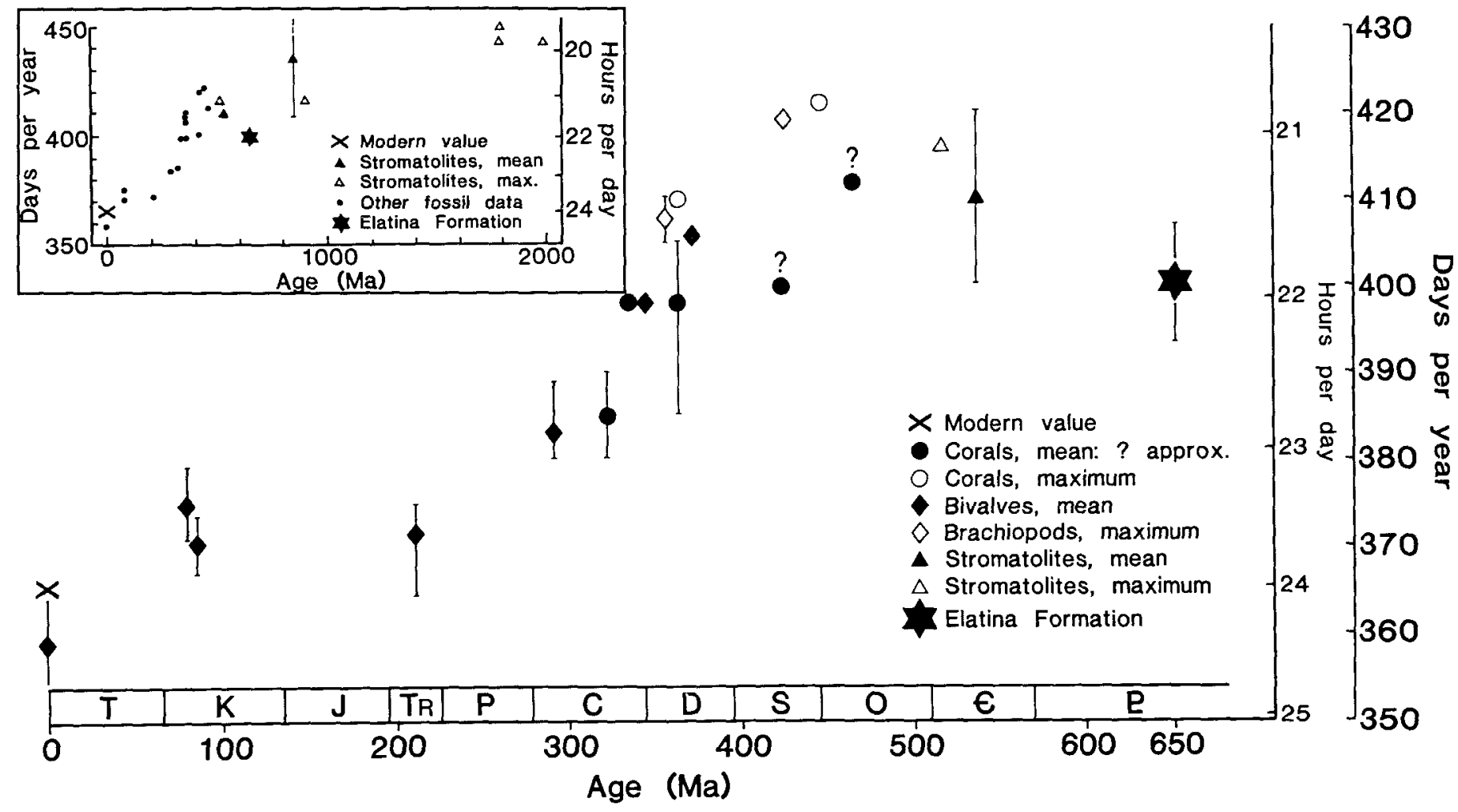

\section{References}

Allen, J.R.L., 1981, Paleotidal speeds and ranges estimated from crossbedding sets with mud drapes: Nature, v. 293. no. 5831, p. 394-396. 1982. Mud drapes in sand-wave deposits: a physical model with applications to the Folkestone Beds (Early Cretaceous. southeast England) Philosophical Transactions of the Royal Society of London. series A. v. 306, no. 1493, p. 291-345.

Berry. W.B.N., and Barker, R.M., 1968, Fossil bivalve shells indicate longer month and year in Cretaceous than present: Nature, v. 217, no. 5132, p. 938-939.

Boothroyd. J.C., 1985, Tidal inlets and tidal deltas, in Davis. R.A., ed., Coastal sedimentary environments: New York, Springer-Verlag, p. $445-532$.

Broadhurst, F.M., 1988. Seasons and tides in the Westphalian, in Besly, B.M., and Kelling. G.. eds.. Sedimentation in a synorogenic basin complex: Glasgow, Blackie and Son, Ltd. p. 264-272.

Brosche, P.. 1984, Tidal friction in the Earth-Moon system: Philosophical Transactions of the Royal Society of London. series A. v. 313, no. 1524 p. $71-75$.

Brosche, P., and Sündermann, J., eds., 1978. Tidal friction and the Earth's rotation: Berlin, Springer-Verlag, $241 \mathrm{p}$.
Campbell, F.H.A.. ed., 1981, Proterozoic basins of Canada: Geological Survey of Canada Paper $81-10,443 \mathrm{p}$.

de Boer. P.L., van Gelder, A., and Nio, S.D., eds., 1988, Tide-influenced sedimentary environments and facies: Dordrecht, Netherlands. Reidel, $530 \mathrm{p}$.

Ewers, W.E., and Morris, R.C. 1981, Studies of the Dales Gorge Member of Brockman Iron Formation. Western Australia: Economic Geology, v. 76. no. 7. p. 1929-1953.

FitzGerald, D.M., and Nummedal, D., 1983, Response characteristics of an ebb-dominated tidal inlet channel: Journal of Sedimentary Petrology, v. 53, no. 3, p. 833-845.

Fralick. P. 1987. Depositional enviromment of Archean iron formation: Inferences from layering in sediment and volcanic hosted end members, in Appel, P.W.U., and LaBerge, G.L., eds., Precambrian iron-formations: Athens, Theophrastus Publications, p. 251-266.

Godin, G., 1972, The analysis of tides: Liverpool, Liverpool University Press, $264 \mathrm{p}$.

Hayes, M.O.. 1989, Modern clastic depositional environments, South Carolina: International Geological Congress, 28th Session, Washington, D.C., 1989. Field Trip Guidebook T371, 85 p. 
Hofmann. H.J., 1973. Stromatolites: Characteristics and utility: Earth-Science Reviews, v. 9, no. 4, p. 339-373.

Imperato, D.P., Sexton, W.J., and Hayes, M.O.. 1988, Stratigraphy and sediment characteristics of a mesotidal ebb-tidal delta, North Edisto Inlet, South Carolina: Journal of Sedimentary Petrology, v, 58, no. 6, p. 950-958.

Kaye, C.A., and Stuckey, G.W.. 1973, Nodal tidal cycle of 18.6 yr.: Geology, v. 1, no. 3, p. 141-144.

Kvale, E.P., Archer, A.W., and Johnson, H.R., 1989, Daily, monthly and yearly tidal cycles within laminated siltstones of the Mansfield Formation (Pennsylvanian) of Indiana: Geology, v. 17, no, 4, p. 365-368.

Lambeck, K. 1978. The Earth's palaeorotation, in Brosche, P.. and Sündermann. J., eds., Tidal friction and the Earth's rotation: Berlin. SpringerVerlag, p. 145-I53,

-1980. The Earth's variable rotation: Geophysical causes and consequences: Cambridge, Cambridge University Press, 449 p.

1988, Geophysical geodesy: The slow deformations of the earth: Oxford, Oxford University Press, $718 \mathrm{p}$.

Lisitzin, E., 1974, Sea-level changes: Amsterdam, Elsevier, 286 p.

Mazzullo, S.J.. 1971. Length of the year during the Silurian and Devonian Periods: Geological Society of America Bulletin, v, 82, no. 4, p. 1085-1086.

McGugan, Alan, 1968, Possible use of algal stromatolite rhythms in geochronology [abs.]: Geological Society of America Special Paper 115, p. 145.

Ozsoy, E., 1986, Ebb-tidal jets: A model of suspended sediment and mass transport at tidal inlets: Estuarine, Coastal and Shelf Science, v. 22, no. 1. p. $45-62$.

Pannella, Giorgio, 1972a, Paleontological evidence on the Earth's rotational history since early Precambrian: Astrophysics and Space Science, v. 16. no. 2, p. 212-237.

1972 b. Precambrian stromatolites as paleontological clocks: International Geological Congress, 24th Session, Montreal, 1972. Proceedings. Section I. p. 50-57.

1975. Palaeontological clocks and the history of the Earth's rotation, in Rosenberg. G.D., and Runcorn. S.K., eds., Growth rhythms and the history of the Earth's rotation: London, John Wiley, p. 253-284.

1976, Geophysical inferences from stromatolite lamination, in Walter, M.R., ed., Stromatolites: Developments in sedimentology 20: Amsterdam, Elsevier, p. 673-685.

Piper, J.D.A., 1982, Movements of the continental crust and lithosphereaesthenosphere systems in Precambrian times, in Brosche, P.. and Sündermann, J., eds., Tidal friction and the Earth's rotation, II: Berlin, Springer-Verlag, p. 253-321.

Preiss, W.V., compiler, 1987. The Adelaide Geosyncline: Adelaide, South Australian Department of Mines and Energy Bulletin 53, $438 \mathrm{p}$.

Rahmani, R.A., 1988, Estuarine tidal channel and nearshore sedimentation of a Late Cretaceous epicontinental sea, Drumheller, Alberta, Canada, in de Boer, P.L., van Gelder. A., and Nio, S.D., eds., Tide-influenced sedimentary environments and facies: Dordrecht, Netherlands, Reidel, p. $433-471$.

Rees, A.I., 1966, Some flume experiments with a fine silt: Sedimentology, v. 6 , no. 3, p. $209-250$.

Rinehart, J.S., 1972a, Fluctuations in geyser activity caused by variations in earth tidal forces, barometric pressure, and tectonic stresses: Journal of Geophysical Research, v. 77 , no. 2, p. 342-350.

-1972b. 18.6-year earth tide regulates geyser activity: Science, v. 177. no, 4046 , p. $346-347$

1974, Geysers: EOS (American Geophysical Union Transactions), v. 56 , no. 12 , p. $1052-1062$.

Rosenberg, G.D., and Runcorn. S.K., eds., 1975, Growth rhythms and the history of the Earth's rotation: London, John Wiley, 559 p.

Runcorn, S.K., 1966, Corals as paleontological clocks: Scientific American, v. 215 , no. 4 , p. $26-33$.

1979. Palaeontological data on the history of the Earth-Moon system: Physics of the Earth and Planetary Interiors, v. 20, no. I, p. pl-p5.

Schopf, J.W., ed., 1983, Earth's earliest biosphere. Its origin and evolution: Princeton, N.J., Princeton University Press, 543 p.

Scrutton. C.T., 1964, Periodicity in Devonian coral growth: Palaeontology, v. 7 , pt. 4 , p. $552-558$.

1970, Evidence for a monthly periodicity in the growth of some corals, in Runcorn, S.K., ed., Palaeogeophysics: London, Academic Press. p. 11-16.
1978. Periodic growth features in fossil organisms and the length of the day and month, in Brosche, P.. and Sündermann, J., eds.. Tidal friction and the Earth's rotation: Berlin, Springer-Verlag, p. 154-196.

Scrutton, C.T., and Hipkin, R.G., 1973, Long-term changes in the rotation rate of the Earth: Earth-Science Reviews, v. 9, no. 3, p. 259-274.

Simonson, B.M., 1985, Sedimentological constraints on the origins of Precambrian iron-formations: Geological Society of America Bulletin. v. 96. no. 2 , p. $244-252$.

Trendall, A.F., 1973, Varve cycles in the Weeli Wolli Formation of the Precambrian Hamersley Group. Western Australia: Economic Geology, y. 68 , no. 7, p. $1089-1097$.

1983, The Hamersley Basin, in Trendall, A.F., and Morris, R.C. eds., Iron-formation: Facts and problems: Amsterdam. Elsevier. p. 69-129.

Trendall, A.F., and Blockley, J.G., 1970, The iron formations of the Precambrian Hamersley Group, Western Australia: Perth, Geological Survey of Western Australia Bulletin 119, 366 p.

Vanyo, J.P., and Awramik, S.M., 1985. Stromatolites and Earth-Sun-Moon dynamics: Precambrian Research, v. 29, nos. 1-3, p. 121-142.

Visser, M.J., 1980, Neap-spring cycles reflected in Holocene subtidal largescale bedform deposits: A preliminary note: Geology, v. 8, no. 11, p. 543-546.

Wells, J.W., 1963, Coral growth and geochronometry: Nature, v. 197, no. 4871, p. $948-950$

-1970 , Problems of annual and daily growth-rings in corals, in Runcorn, S.K., ed., Palaeogeophysics: London, Academic Press, p. 3-9.

Williams, G.E., 1987, Cosmic signals laid down in stone: New Scientist, v. 114, no. 1566 , p. $63-66$

1988, Cyclicity in the late Precambrian Elatina Formation, South Australia: Solar or tidal signature?: Climatic Change, v. 13, no. 2, p. $117-128$.

1989a, Late Precambrian tidal rhythmites in South Australia and the history of the Earth's rotation: Journal of the Geological Society of London, v. 146, no. 1. p. 97-111.

$-1989 \mathrm{~b}$, Precambrian tidal sedimentary cycles and Earth's paleorotation: EOS (American Geophysical Union Transactions), v, 70, no, 3, p. $33,40-41$.

-1989 c, Precambrian cyclic rhythmites: Solar-climatic or tidal signatures?: Philosophical Transactions of the Royal Society of London, series A [in press].

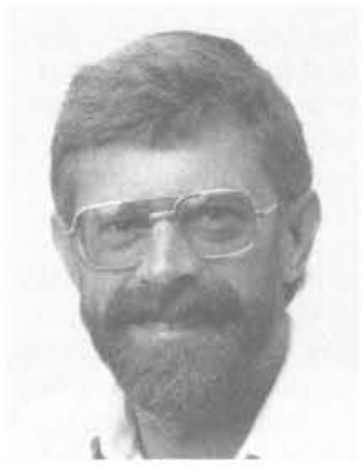

Dr. G.E. Williams is Visiting Research Fellow in the Department of Geology and Geophysics, University of Adelaide (GPO Box 498. Adelaide. South Australia 5001, Australia) and Principal Geologist with BHP-Utah Minerals International in Adelaide. A graduate of the University of Melbourne and the University of Reading in sedimentology, his main interests include the Earth's climatic history and planetary history as revealed by sedimentary rocks, as well as exploration for economic mineral deposits in sedimentary basins. 